\title{
SOSIALISASI PEMANFAATAN SOFTWARE OPEN SOURCE DI SMK MUHAMMADIYAH 1 SURAKARTA
}

\author{
Husni Thamrin ${ }^{1)}$, Dedi Ary Prasetya ${ }^{2)}$, dan Ady Purna Kurniawan ${ }^{1)}$ \\ 1) Jurusan Teknik Informatika \\ 2) Jurusan Teknik Elektro \\ Universitas Muhammadiyah Surakarta
}

\begin{abstract}
Embrace of open source software (OSS) has not been widespread although users of OSS will gain a lot of benefits and the society and the nation will get many advantages. This writing describes an observation to the understanding and attitude of a group of students towards the use of OSS. The students come from SMK Muhammadiyah 1 Surakarta which is a vocational school in Surakarta owned by Muhammadiyah organization. A survey was conducted during an OSS campaign. Students were faced with two sets of questionnaires; the first set was given prior and the seoncd after the campaign. The first set was aimed at identifying the computer literacy of the students and their understanding of the open source concept. The second set was aimed at exploring their understanding and attitude towards the use of OSS. Observation showed that the campaign activity improved students understanding of open source concept and enhance their attitude to use OSS. However, students were to some extent pragmatic when they were opted to select which software to use to accomplish a task.
\end{abstract}

Kata kunci: sosialisasi, software open source, software terbuka

\section{PENDAHULUAN}

\section{Analisis Situasi}

Adopsi teknologi dalam kehidupan manusia telah mencapai berbagai sisi mulai dari kehidupan pribadi, sosial, lembaga hingga pemerintahan. Manusia sudah semakin menyatu dengan teknologi. Lembaga pendidikan tidak luput dari sentuhan teknologi dan sudah lama dikenal istilah teknologi pendidikan yang merupakan pengembangan dan implementasi teknologi dalam proses pembelajaran, desain kurikulum hingga evaluasi pembelajaran dan evaluasi sistem pendidikan.

Berbagai lembaga pendidikan mem-punyai kemampuan dan pengalaman yang bervariasi dalam tingkat penggunaan teknologi pendidikan. Pada saat ini laboratorium komputer sudah disadari sebagai kebutuhan dasar namun belum semua sekolah mampu membangunnya. Kebanyakan laboratorium komputer sekolah masih menggunakan software proprietary namun pengadaanya tidak melalui proses yang seharusnya. Salah satu kendala suatu lembaga khususnya lembaga pendidikan tidak menggunakan software asli adalah karena mahalnya harga lisensi software. Sebuah sistem operasi proprietary seperti Microsoft Windows Home Edition berharga tak kurang dari USD 100 untuk setiap kopinya sehingga sebuah laboratorium komputer dengan 30 workstation membutuhkan USD 
3000 hanya untuk lisensi sistem operasi. Nilai ini akan bertambah besar jika digunakan sistem operasi untuk server dan software untuk paket Office.

Penggunaan software bajakan di lembaga pendidikan sangat tidak dikehendaki. Menggunakan software bajakan berarti melanggar hukum, baik hukum positif maupun hukum agama. Lembaga pendidikan yang seharusnya mengajarkan siswa nilai dan karakter yang luhur seharusnya bersih dari praktek pelanggaran hukum. Guru tidak boleh memberi contoh tidak baik kepada para siswa termasuk dalam bentuk penggunaan software secara tidak legal.

Penggunaan software bajakan dapat dihindari karena telah tersedia software open source yang dapat diunduh dan digunakan tanpa membeli lisensi. Kemampuan software open source sangat beragam. Jika ditandingkan dengan software proprietary, sebagian software open source mempunyai kemampuan lebih baik, sebagian mempunyai kemampuan yang sebanding meskipun sebagian lain masih belum memadai. Biaya yang digunakan untuk adopsi software open source hanya terletak pada instalasi dan perawatan sehingga secara total cost akan jauh lebih murah dibanding biaya adopsi software proprietary.

Tidak banyak masyarakat yang mengenal software open source. Sedikit sekali yang tahu bahwa kebanyakan kegiatan komputasi (kegiatan dengan komputer) dapat dilakukan menggunakan software open source. Oleh karena itu penulis berupaya membantu khalayak sasaran untuk mengenal tentang software open source dan membantu dalam proses instalasi dan perawatan awalnya.

\section{Perumusan Masalah}

Dari analisis situasi di atas, dirumuskan permasalahan yang ingin dipecahkan melalui kegiatan sosialisasi sebagai berikut. a. Bagaimana siswa dan guru mendapat pengertian tentang open source dan mengenal software open source?

b. Bagaimana siswa dan guru mengetahui apa saja yang dapat dilakukan software open source, cara mendapatkan dan menggunakannya?

\section{Tinjauan Pustaka}

Software open source adalah istilah yang digunakan untuk software yang membuka/membebaskan source code-nya untuk dilihat oleh orang lain dan membiarkan orang lain mengetahui cara kerja software tersebut dan sekaligus memperbaiki kelemahan-kelemahan yang ada pada software tersebut. Salah satu keunggulan software open souce adalah bahwa software dapat digunakan tanpa membayar lisensi. Biasanya orang mendapatkan software ini dari internet. Salah satu open source software yang terkenal yaitu Linux.

Pengembangan software open source melibatkan banyak orang dari berbagai penjuru dunia yang berinteraksi melalui internet. Terdapat berbagai macam software yang dibuat secara open source, mulai dari sistem operasi, paket office, aplikasi multimedia, hingga aplikasi untuk berkomunikasi. Pola pengembangan open source telah melahirkan developer-developer handal dari berbagai penjuru dunia.

Biaya total penggunaan software open source jauh lebih murah dibanding penggunaan software proprietary. Itulah sebabnya pemanfaatan software ini cocok dilakukan di Indonesia sebagai negara berkembang yang masih membutuhkan banyak dana untuk pembangunan. Penggunaan software proprietari akan menambah beban anggaran pemerintah. Diperkirakan nilai bisnis software di Indonesia mencapai 1 triliun rupiah per tahun. Jika $70 \%$ kebutuhan software ini dipenuhi menggunakan software 
open source, dapat dibayangkan seberapa besar devisa negara yang dihemat. Itulah sebabnya pemerintah sejak tahun 2004 telah mulai menggalakkan penggunaan software open source. Upaya terakhir pemerintah dalam penggunaan software open source dimunculkan dalam bentuk surat edaran Menteri Pendayaan Aparatur Negara nomor SE/01/M.PAN/3/2009 yang memerintahkan semua kementrian, lembaga pemerintahan negara hingga kabupaten serta BUMN untuk mulai menggunakan software legal dan open source selambatnya Desember 2011.

\section{Tujuan dan Manfaat}

Tujuan dari kegiatan sosialisasi pemanfatan sofware open source di SMK Muhammadiyah 1 Surakarta adalah sebagai berikut.

a. Mengenalkan latar belakang serta pengertian software open source.

b. Memberikan ilustrasi dan pengenalan berbagai software open source yang dapat dimanfaatkan khususnya di laboratorium sekolah.

c. Membantu menginstal software open source di laboratorium sekolah dan mengenalkan cara perawatan sederhana.

Manfaat yang bisa diambil dari kegiatan ini adalah:

a. Bagi dosen kegiatan ini dapat mengembangkan profesi dosen dan media mendapatkan pengalaman dalam mengorganisasikan sebuah pelatihan. Juga sebagai sarana transfer ilmu pengetahuan dan teknologi dari dosen kepada masyarakat untuk meningkatkan kualitas kehidupan mereka

b. Bagi mahasiswa kegiatan ini dapat digunakan untuk memperkenalkan diri dan eksistensinya kepada masyarakat dalam bidang ilmu pengetahuan dan teknologi khususnya dalam hal software open source untuk pendidikan. c. Bagi sekolah kegiatan ini merupakan media meningkatkan kualitas SDM khususnya guru dan siswa.

\section{METODE PELAKSANAAN}

Pengabdian yang berupa sosialisasi pemanfaatan software open source dilakukan dua tahap yaitu sosisalisasi kepada guru produktif dan sosialisasi kepada siswa.

Sosialisasi kepada siswa didahului dengan survei pengenalan komputer dan software open source, kemudian diakhiri dengan survei pengetahuan dan sikap terhadpa software open source.

\section{Sosialisasi kepada guru produktif}

Sosialisasi kepada guru produktif dilaksanakan di laboratorium komputer SMK Muhammadiyah I Surakarta. Yang dimaksud dengan guru produktif adalah guru pada mata pelajaran yang sebidang dengan jurusan pada SMK. Jumlah guru yang mengikuti kegiatan adalah 15 orang.

Kegiatan diisi diawali dengan ceramah tentang pengertian open source, pengertian software berbayar dan software bebas, keuntungan dan kekurangan penggunaan open source software (OSS), dan jenis-jenis OSS.

Ceramah disertai dengan demonstrasi penggunaan OSS mulai dari desktop, paket office, aplikasi multimedia, hingga paket software yang dapat dimanfaatkan oleh guru dan siswa SMK jurusan Mesin dan Otomotif. Kegiatan diakhiri dengan tanya jawab.

\section{Sosialisasi kepada siswa}

Sosialisasi kepada siswa dilaksanakan di ruang internet, perpustakaan Universitas Muhammadiyah Surakarta. Jumlah siswa yang mengikuti kegiatan adalah 20 orang dengan didampingi oleh 2 orang guru.

Sebelum kegiatan sosialisasi dilakukan, para siswa diminta mengisi kuesioner online yang 
telah dipersiapkan di situs www.surveymonkey.com. Pertanyaan kuesioner ini terkait literasi para siswa terhadap komputer dan pengetahuan tentang berbagai istilah yang sering dijumpai di dunia komputer khususnya dunia open source.

Kegiatan pertama berupa ceramah tentang desktop gnome dimaksudkan untuk membuat siswa familiar dengan menu-menu yang terdapat dalam sistem operasi GNU/ Linux dan Desktop populer yang sering digunakan. Kegiatan berikutnya adalah ceramah tentang OpenOffice dimaksudkan untuk mengenalkan siswa dengan paket perkantoran yang tergolong open source, yang populer dan banyak digunakan.

Kegiatan ceramah berikutnya mengambil topik perancangan grafis dan animasi (animation and graphics design). Pada kegiatan ini didemonstrasikan hasil animasi dan game yang dirancang menggunakan perangkat lunak open source seperti Blender. Kesempatan ini dipergunakan juga untuk memperlihatkan desain grafis menggunakan GIMP dan InkScape.

Kegiatan sosialisasi diakhiri dengan pengisian kuesioner yang telah dipersiapkan di situs wWw.surveymonkey.com. Isi pertanyaan meliputi pengertian open source dan sikap siswa terhadap pemanfaatan OSS.

\section{HASIL DAN PEMBAHASAN}

Berdasarkan hasil diskusi dan tanya jawab antara penulis dan para guru produktif diperoleh gambaran bahwa para guru mulai memahami tentang OSS dan urgensi pemanfaatan OSS. Beberapa guru nampak antusias dan seakan mengharuskan penggunaan OSS ini secara segera. Namun tidak sedikit guru memperlihatkan perasaan khawatir membayangkan konsekuensi jika diharuskan beralih menggunakan OSS. Beberapa kendala yang terungkap adalah keharusan untuk belajar lagi dan bayangan akan kesulitan menghadapi hal baru sedangkan tugas utama para guru sebagai pengajar sangat banyak.

Sedangkan terhadap para siswa di samping diberikan ceramah tentang OSS, dilakukan juga survei sebelum dan setelah ceramah tentang pemahaman dan sikap siswa terhadap OSS. Survei di awal ceramah terdiri atas 6 pertanyaan tertutup dan 4 pertanyaan terbuka dan ditambah isian tentang identitas. Uraian berikut terkait hasil survei terhadap para siswa.

\section{Literasi Komputer dan Pemahaman Siswa terhadap OSS}

Survei sebelum kegiatan sosialisasi terdiri atas dua kelompok pertanyaan. Pertanyaan kelompok pertama terkait dengan interaksi dan literasi siswa dengan komputer. Hasil pengisian kuesioner ditampilkan pada Gambar 1 - Gambar 2.

Ketika siswa ditanya bagaimana cara mengakses komputer, kebanyakan siswa menjawab bahwa akses diperoleh melalui sewa di warung internet. Kebanyakan siswa tidak mempunyai komputer. Hanya $15 \%$ siswa yang mempunyai komputer di rumah. Sedikitnya siswa yang memiliki komputer di rumah mempunyai implikasi terhadap tingkat interaksi siswa dengan komputer. Implikasi ini nampak dari jawaban siswa terhadap pertanyaan tentang lamanya akses komputer dalam seminggu (lihat Gambar 1). Kebanyakan siswa yaitu mencapai $85 \%$ mengakses komputer kurang dari 7 jam seminggu, bahkan $45 \%$ mengakses komputer kurang dari 2 jam per minggu. 


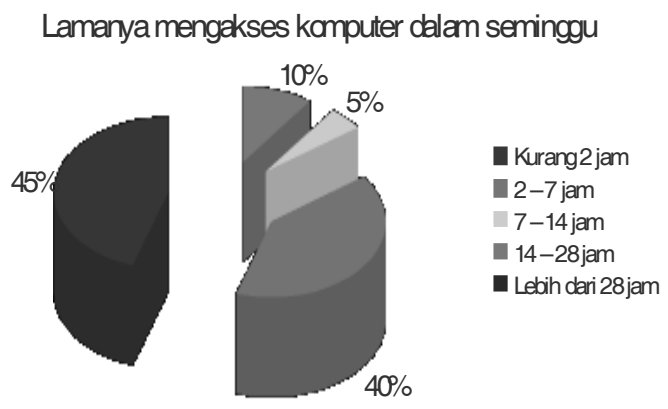

Gambar 1. Jawaban siswa terhadap pertanyaan rata-rata rentang waktu mengakses komputer dalam seminggu

Dapat diduga bahwa akses terhadap komputer oleh siswa dilakukan di sekolah karena sebagaimana diungkap oleh guru pendamping para siswa mendapat pelajaran komputer selama dua jam pelajaran seminggu. Informasi yang cukup menarik untuk dicermati adalah penggunaan komputer oleh siswa. Kegiatan yang dipersepsikan sangat sering dilakukan oleh siswa secara berturut turut adalah akses ke situs jejaring sosial (30\%) dan bermain game (15\%) sebagaimana terlihat pada Gambar 2. Kegiatan yang dipersepsikan cukup sering hingga sangat sering dilakukan adalah akses ke situs jejaring sosial, membaca berita atau informasi pengetahuan dan bermain game. Kebanyakan siswa menyatakan jarang atau tidak pernah menggunakan komputer untuk melakukan hal serius seperti menggunakan aplikasi Office.

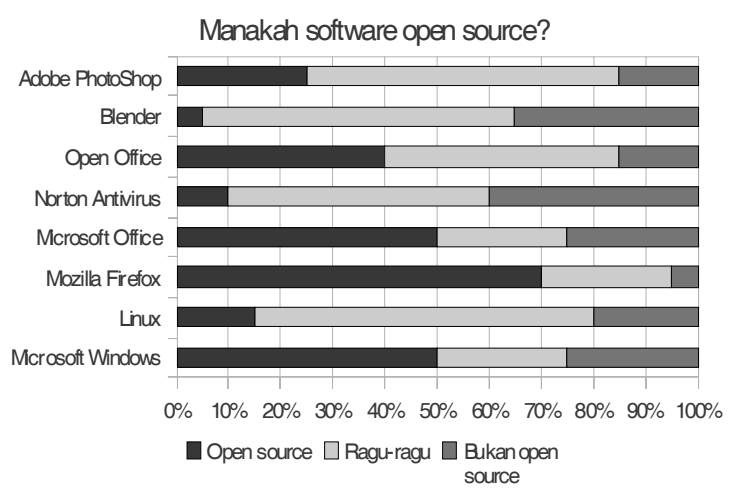

Gambar 2. Aktivitas siswa dengan komputer
Kelompok pertanyaan kedua dalam kuesioner awal digunakan untuk mengidentifikasi pengetahuan siswa tentang software open source. Terhadap pertanyaan terbuka tentang pengertian beberapa istilah software, tidak ada siswa yang dapat menjawab seluruh pertanyaan dengan baik.

Pertanyaan tertutup dalam kelompok pertanyaan kedua berupaya mengidentifikasi apakah siswa mengenal software open source. Dari empat nama software open source yang sangat populer, siswa sering menggunakan salah satunya yaitu Mozilla Firefox (lihat Gambar 3). Sedikit sekali siswa yang pernah atau sering menggunakan Linux atau Open Office dan banyak yang belum pernah mendengar kedua software itu. Nyaris tidak ada siswa yang mengenal software grafis GIMP.

Terhadap tiga nama software proprietari yang populer, hampir semua siswa menyatakan pernah atau sering memakai. Ketiganya adalah Microsoft Windows, Microsoft Word dan Internet Explorer. Meskipun mengherankan, terdapat siswa yang mempersepsikan diri tidak mengenal Microsoft Windows.

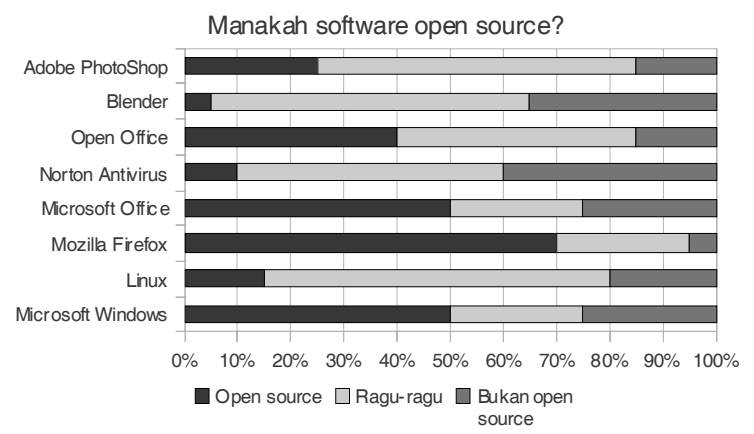

Gambar 3. Tingkat pengenalan siswa atas software yang cukup populer penggunaannya 


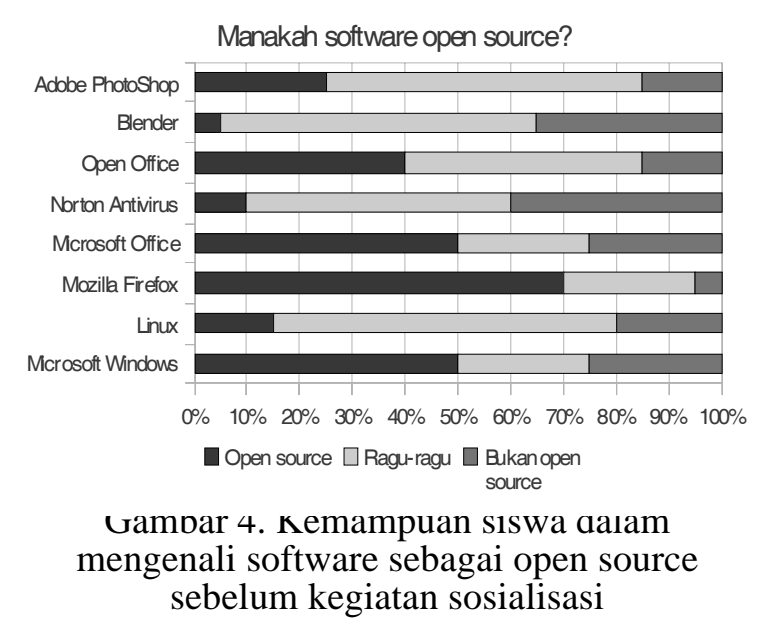

Meskipun terdapat software open source yang populer dan sering digunakan oleh para siswa, mereka secara umum tidak mengenal software open source. Ketika siswa diminta mengidentifikasi delapan buah software yang cukup populer, secara rata-rata hanya $29 \%$ pertanyaan dijawab dengan benar (lihat Gambar 4). Kebanyakan siswa memberi jawaban ragu-ragu yaitu mencapai $44 \%$ dari seluruh jawaban yang ada.

\section{Pemahaman dan Sikap siswa Ter- hadap OSS}

Survei akhir terdiri atas tujuh pertanyaan tertutup dan satu pertanyaan terbuka. Empat pertanyaan pertama berupaya mengidentifikasi pengetahuan siswa terhadap istilah yang sering muncul dalam dunia software dan distribusinya, yaitu pengertian freeware, free software, open source software dan lisensi. Dari empat pertanyaan itu, dua sangat terkait dengan dunia open source yaitu open source software dan lisensi dan persentase jawaban benar terhadap pertanyaan tentang kedua istilah itu adalah cukup tinggi yaitu 95\% dan $79 \%$.

Pertanyaan berikutnya terkait dengan pengenalan siswa akan software yang tergolong open source. siswa dihadapka pada daftar nama sepuluh software dan diminta menentukan mana yang open source dan mana yang bukan. Secara rata-rata, siswa dapat mengidentifikasi beberapa software dengan tepat. Lebih dari $70 \%$ siswa menyatakan bahwa Blender dan Linux adalah OSS, dan lebih dari $80 \%$ siswa tidak menyatakan bahwa Powerpoint, Excel, Word, Norton Antivirus, Adobe Photoshop dan Microsoft Windows sebagai OSS. Namun secara rata-rata siswa tidak cukup tegas menyatakan bahwa Mozilla Firefox dan Open Office sebagai OSS, hanya $50 \%$ saja yang memberi jawaban positif.

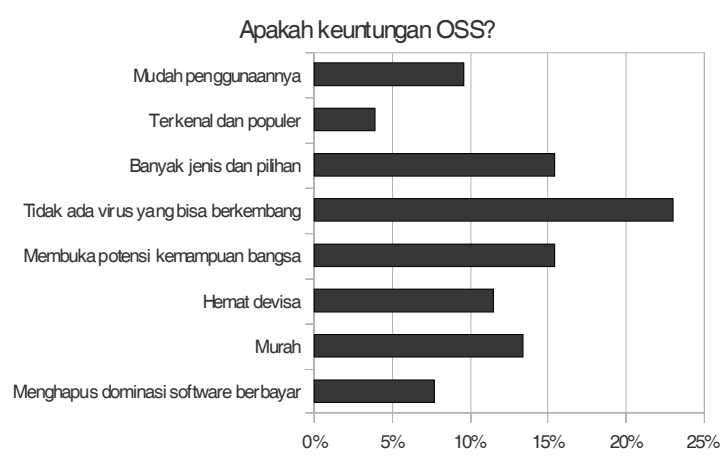

Gambar 5. Persepsi siswa tentang keuntungan pemanfaatan software open source

Ketika siswa ditanya tentang keuntungan penggunaan OSS, jawaban yang paling banyak dipilih (yaitu 23\%) adalah tidak adanya virus yang bisa berkembang pada OSS. Keuntungan lain yang banyak dipersepsikan siswa adalah keberagaman jenis OSS, membuka potensi kemampuan bangsa dan harga yang murah (lihat Gambar 5). Pertanyaan penting pasca kegiatan sosialisasi adalah sikap siswa apakah mau menggunakan OSS. Siswa diminta memilih dua software yang setara, satu merupakan OSS dan yang lain merupakan software proprietari. Secara total $47 \%$ siswa cenderung memilih OSS, $46 \%$ memilih software proprietari dan $6 \%$ ragu-ragu. Jika dicermati lebih lanjut, terlihat bahwa siswa cenderung memilih OSS pada 5 jenis software dari 8 software yang ditanyakan yaitu untuk software editor gambar, desain 
model 3D, editor citra berbasis vektor, sistem operasi dan web browser (lihat Gambar 6). Sebaliknya siswa cenderung memilih software proprietari pada 3 jenis software yaitu software presentasi, spreadsheet dan pengolah kata.

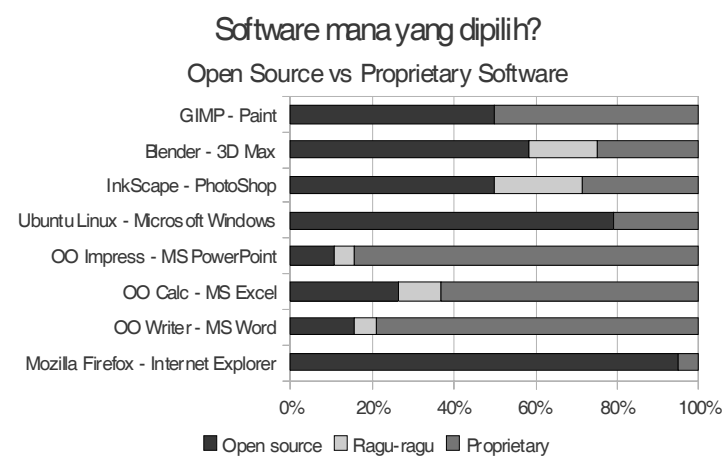

Gambar 6. Pilihan yang diambil siswa terhadap pemakaian software apakah yang open source atau bukan open source

\section{SIMPULAN DAN SARAN}

\section{Simpulan}

Pemahaman dan sikap guru dan siswa SMK Muhammadiyah 1 Surakarta terhadap pemanfaatan software open source (OSS) dapat ditingkatkan dan diperbaiki melalui kegiatan sosialisasi. Pada umumnya siswa dapat melihat dan menyadari keuntungan penggunaan OSS namun pragmatisme masih cukup besar mempengaruhi sikap siswa dalam memilih software yang digunakan.

\section{Saran}

Perbaikan pemahaman dan sikap peserta kegiatan menunjukkan bahwa sosialisasi perlu dilakukan agar masyarakat semakin menerima dan nyaman menggunakan software open source.

Untuk menghadapi sikap pragmatisme masyarakat dalam memilih software, perlu dipersiapkan materi sosialisasi yang lebih baik yang membedakan sifat kegiatan antara sosialisasi dan workshop. Jika diinginkan agar masyarakat beralih dari software yang ada ke software open source, mereka perlu dilatih dalam kegiatan workshop agar mereka segera terbiasa dengan software yang dianggap "baru".

\section{DAFTAR PUSTAKA}

2009. "Pemanfaatan Perangkat Lunak Legal dan Open Source Software (OSS)", Website Mahkamah Agung Republik Indonesia diakses Mei 2009. <www.mahkamahagung.go.id/images/uploaded/15092009.pdf>

DiBona, C., Ockman, S., Stone, M., 2000. "Introduction" in Open Sources: Voices from the Open Source Revolution, California: O'Reilly and Associates Inc.

Favier, L., Mekhantar, J., Terrasse, M., 2007. "Use of OSS by Local e-Administration: The French Situation," in Handbook of Research on Open Source Software: Technological, Economic and Social Perspectives, Kirk St. Amant, Brian Still, Ed. New York: Information Science Reference, pp. 428 - 444.

Hahn, R. W., 2002. "Government Policy towards Open Source Software: An Overview," in Government Policy towards Open Source Software, Robert W. Hahn, Ed. Washington: Brookings Institution Press.

Thamrin, H, 2011. "Embracing Open Source Software to Empower Potentials of the Community," in Proc. ISIGW 2011, Surakarta, Indonesia: Muhammadiyah University Press. 